\title{
TEMPORAL AND SPATIAL VARIABILITY OF HEAT LOAD IN SZCZECIN
}

\section{CZASOWA I PRZESTRZENNA ZMIENNOŚĆ OBCIAZZEŃ CIEPLNYCH W SZCZECINIE}

Department of Meteorology and Landscape Architecture, West Pomeranian University of Technology, Szczecin, Poland

\begin{abstract}
Streszczenie. Na podstawie wartości temperatury powietrza, wilgotności względnej powietrza, prędkości wiatru i zachmurzenia (wg godzin) obliczono bezwymiarowy wskaźnik obciążenia cieplnego - Heat Load (HL) dla dwóch stacji w Szczecinie reprezentujących ścisłe centrum miasta (ul. Piłsudskiego) i jego północne obrzeża (ul. Łączna). Analiza wartości wskaźnika obciążeń cieplnych HL w latach 2005-2010 wskazuje na wyraźne zarówno przestrzenne, jak i czasowe zróżnicowanie warunków biotermicznych w Szczecinie. Stwierdzono, że - niezależnie od rozpatrywanego przedziału czasowego - większe wartości HL notowane były w centrum niż na obrzeżach miasta. Warunki oszczędzające $(\mathrm{HL} 0,931-1,185)$ występowały ze średnią w roku częstością wynoszącą $52 \%$ dni w centrum do $44 \%$ dni na przedmieściach. Z kolei warunki wpływające hartująco ( $\mathrm{HL} 0,811-0,930,1,186-1,600)$ na organizm człowieka stanowiły łącznie $38 \%$ (ul. Piłsudskiego) i 29\% (ul. Łączna). Najbardziej niesprzyjające warunki biotermiczne $(\mathrm{HL} \leq 0,750 \geq 1,750)$, silnie obciążające układ termoregulacyjny człowieka, występowały tylko w $10 \%$ dni w roku w centrum miasta i aż w $27 \%$ dni na jego przedmieściach.
\end{abstract}

Key words: agglomeration, bioclimate, thermal stress, HL index.

Słowa kluczowe: aglomeracja, bioklimat, stres termiczny, wskaźnik HL.

\section{INTRODUCTION}

The human organism is subject to various factors of atmospheric environment affecting thermal sensation and heat load, well-being and even health. Such factors continually affect our organisms in a complex manner, with different intensity depending on temporal and spatial characteristics. Determination of the effect of the atmospheric environment, including the specific urban area, on human health and life is the basis of bioclimatic research. Among the local factors, the structure of the developed areas has the greatest effect on the bioclimatic conditions as it modifies the amount of incoming solar radiation and air movement, thus affects the biothermal conditions. Distinct bioclimate of the city is reflected in, among others, increase in onerousness and load in terms of thermal subjective conditions, and in the prevalence of urban heat island (UHI) (Błażejczyk et al. 2014). Particularly during hot and sweltering periods, $\mathrm{UHI}$ hinders heat transfer and regeneration in the evening and at night.

Corresponding author - Adres do korespondencji: Agnieszka Mąkosza, Department of Meteorology and Landscape Architecture, West Pomeranian University of Technology, Szczecin, Papieża Pawła VI 3A, 71-459 Szczecin, Poland, e-mail: agnieszka.makosza@zut.edu.pl 
Warm stress occurs usually during heatwave with the inflow of very warm and humid tropical air-masses (Krawczyk 2003). In such conditions, with the increase in intensity of warm stress, heat transfer is impaired by decreased evaporation of sweat from the surface of the skin due to high air humidity and, as a result, the thermoregulatory system is overloaded (Kozłowska-Szczęsna et al. 2004). Cold stress is most often connected with low temperature which causes the organism to lose more heat than it produces and, as a result, the thermal balance is disturbed. The temperature inside the human body decreases gradually. Medical conditions develop when the temperature decreases by $2.6^{\circ} \mathrm{C}$, and if the body temperature drops to below $35^{\circ} \mathrm{C}$ the central thermoregulatory functions stop and the person may experience lightheadedness (Bogucki 1999).

One of the methods of assessment of biothermal conditions in a given area is the use of complex indices based on models of heat exchange between the human body and environment. The characteristics of biothermal conditions of the whole area of Poland, developed with the use of various indices (HL, UTCI) describing heat load, were presented by Krawczyk (2001, 2003) and Błażejczyk (2003). There are studies which present the characteristics of other smaller areas in Poland (the region and the city), such as the work on temporal and spatial variability of heat load in Lubuskie voivodeship with special reference to comfort (Mąkosza 2013). Among the research on heat load in agglomeration area, it is worthwhile to mention the study by Błażejczyk et al. (2014) on heat load in Warsaw and the coexistent urban heat island, the study by Nidzgorska-Lencewicz (2015) on the characteristics of aerosanitary conditions in the Gdańsk agglomeration with relation to heat load, as well as the study by Dobek and Krzyżewska (2016) on the characteristics of the bioclimate of Lublin.

In the present paper, the thermal load of the thermoregulatory system is assessed with the use of heat load index $\mathrm{HL}$, the values of which were the grounds for characterisation of temporal and spatial variability of biothermal conditions in the Szczecin agglomeration.

\section{MATERIAL AND METHODS}

The basis for the research were the hourly values of temperature and air humidity, wind speed and cloudiness from the period 2005-2010. The meteorological data were obtained from the Provincial Environmental Protection Inspectorate (WIOŚ), with the exception of data on cloudiness which were obtained from the Institute of Meteorology and Water Management (IMGW) located in Szczecin-Dąbie.

The data obtained from WIOŚ came from the stations located in two areas representing the very centre of the city characterised by a densely built-up area (Piłsudskiego Street) and dispersed building development on the northern outskirts of the city (Łączna Street). The location of the measuring points is presented in Fig.1. 


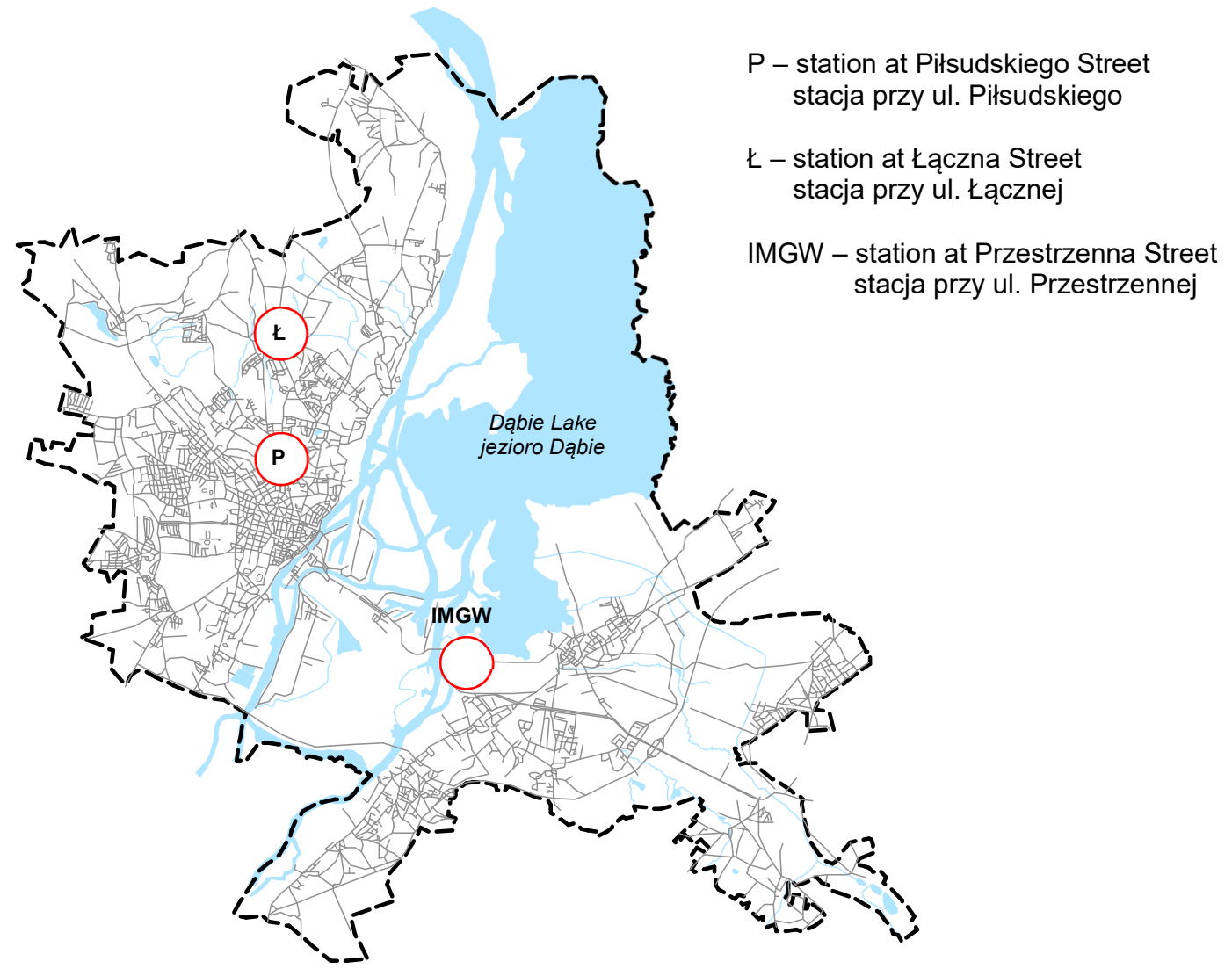

Fig. 1. Location of WIOŚ and IMGW stations in Szczecin

Ryc. 1. Lokalizacja stacji pomiarowych WIOŚ i IMGW w Szczecinie

In order to determine the heat load of the human body, a dimensionless index of heat load $(\mathrm{HL})$, based on the man-environment heat exchange model - MENEX, was used. This index is relatively rarely used in studies on bioclimate. It is a combination of net heat storage (S), absorbed solar radiation (R), and heat loss by evaporation (E) (Błażejczyk 2004; Kozłowska-Szczęsna et al. 2004). The formula used for calculating the index value as developed by the aforementioned authors is:

- when $\mathrm{S}<0\left(\mathrm{~W} \cdot \mathrm{m}^{-2}\right)$ and $\mathrm{E} \geq-50\left(\mathrm{~W} \cdot \mathrm{m}^{-2}\right), \mathrm{HL}=[(\mathrm{S}+1000) / 1000]^{[(5 /(1+R)]}$

- when $S \geq 0\left(\mathrm{~W} \cdot \mathrm{m}^{-2}\right)$ and $E \geq-50\left(\mathrm{~W} \cdot \mathrm{m}^{-2}\right), \mathrm{HL}=[(\mathrm{S}+1000) / 1000]^{[(2-1 /(1+R)]}$

- when $\mathrm{S}<0\left(\mathrm{~W} \cdot \mathrm{m}^{-2}\right)$ and $\mathrm{E}<-50\left(\mathrm{~W} \cdot \mathrm{m}^{-2}\right), \mathrm{HL}=(\mathrm{E} /-50) \cdot[(\mathrm{S}+1000) / 1000]^{[(5 /(1+R)]}$

- when $\mathrm{S} \geq 0\left(\mathrm{~W} \cdot \mathrm{m}^{-2}\right)$ and $\mathrm{E}<-50\left(\mathrm{~W} \cdot \mathrm{m}^{-2}\right), \mathrm{HL}=(\mathrm{E} /-50) \cdot[(\mathrm{S}+1000) / 1000]^{[(2-1 /(1+R)]}$

The numerical coefficients 1.5 and 1000 are expressed in $\mathrm{W} \cdot \mathrm{m}^{-2}$. If the value of $\mathrm{S}$ is lower than $-1000 \mathrm{~W} \cdot \mathrm{m}^{-2}, \mathrm{~S}$ is adopted to be $-1000 \mathrm{~W} \cdot \mathrm{m}^{-2}$.

Individual, calculated values (range) of $\mathrm{HL}$ index correspond to specific heat load and biothermal conditions (Kozłowska-Szczęsna et al. 1997; Błażejczyk 2004). 
Table 1. Classification of heat load and biothermal conditions on the basis of $\mathrm{HL}$ index

Tabela 1. Klasyfikacja obciążeń cieplnych i warunków biotermicznych na podstawie wskaźnika HL

\begin{tabular}{|c|c|c|}
\hline $\mathrm{HL}$ & $\begin{array}{c}\text { Heat load } \\
\text { Obciążenie cieplne }\end{array}$ & $\begin{array}{l}\text { Biothermal conditions } \\
\text { Warunki biotermiczne }\end{array}$ \\
\hline$\leq 0.750$ & $\begin{array}{l}\text { very strong cold stress } \\
\text { bardzo duży stres zimna }\end{array}$ & \multirow{2}{*}{$\begin{array}{l}\text { burdening conditions } \\
\text { warunki obciążające }\end{array}$} \\
\hline $0.750-0.810$ & $\begin{array}{l}\text { strong cold stress } \\
\text { duży stres zimna }\end{array}$ & \\
\hline $0.811-0.870$ & $\begin{array}{l}\text { moderate cold stress } \\
\text { umiarkowany stres zimna }\end{array}$ & \multirow{2}{*}{$\begin{array}{l}\text { toughening conditions } \\
\text { warunki hartujące }\end{array}$} \\
\hline $0.871-0.930$ & $\begin{array}{l}\text { slight cold stress } \\
\text { mały stres zimna }\end{array}$ & \\
\hline $0.931-0.970$ & $\begin{array}{l}\text { very slight cold stress } \\
\text { bardzo mały stres zimna }\end{array}$ & \multirow{3}{*}{$\begin{array}{l}\text { saving condtions } \\
\text { warunki oszczędzające }\end{array}$} \\
\hline $0.971-1.080$ & $\begin{array}{l}\text { thermoneutral conditions } \\
\text { warunki termoneutralne }\end{array}$ & \\
\hline $1.081-1.185$ & $\begin{array}{l}\text { very slight warm stress } \\
\text { bardzo mały stres ciepła }\end{array}$ & \\
\hline $1.186-1.415$ & $\begin{array}{l}\text { slight warm stress } \\
\text { mały stres ciepła }\end{array}$ & \multirow{2}{*}{$\begin{array}{l}\text { toughening conditions } \\
\text { warunki hartujące }\end{array}$} \\
\hline $1.416-1.600$ & $\begin{array}{l}\text { moderate warm stres } \\
\text { umiarkowany stres ciepła }\end{array}$ & \\
\hline $1.601-1.750$ & $\begin{array}{l}\text { strong cold stress } \\
\text { duży stres ciepła }\end{array}$ & \multirow{2}{*}{$\begin{array}{l}\text { burdening conditions } \\
\text { warunki obciążające }\end{array}$} \\
\hline$\geq 1.750$ & $\begin{array}{l}\text { very strong warm stress } \\
\text { bardzo duży stres ciepła }\end{array}$ & \\
\hline
\end{tabular}

Source - Źródło: Kozłowska-Szczęsna et al. (1997, 2002).

\section{RESULTS AND DISCUSSION}

In the analysed period of 2005-2010, mean annual values of HL index in Szczecin ranged from 0.986 to 1.027 at Piłsudskiego Street, and from 0.932 to 0.984 in the vicinity of Łączna Street. The highest values of HL index in both stations were recorded in 2006 and 2008. In turn, the average lowest values were recorded in 2007 and 2009. As per months, the average lowest HL values were recorded in January $(P-0.867, \nvdash-0.802)$ and in December $(P-0.881$, $Ł-0.813)$, and the highest in July $(P-1.286, \nvdash-1.222)$ as presented in Table 2 .

Regardless of the analysed time period, $\mathrm{HL}$ values were higher in the city centre than on the outskirts of Szczecin which reflects the specific thermal regime characteristic for the city area. The studies on the bioclimate of cities indicate a clear variation in thermal sensations and load in the city agglomeration, as has been shown for Szczecin by Czarnecka et al. (2011), Nidzgorska-Lencewicz and Mąkosza (2013), for Gdańsk by Nidzgorska-Lencewicz (2015), for Warszawa by Błażejczyk et al. (2014) and for Lublin by Dobek and Krzyżewska (2016).

From the perspective of the human organism, of particular importance is the variability of heat load during the 24-hour period. A substantially greater daily amplitude of $\mathrm{HL}$ index is recorded from May to September (0.3-0.7) with a peak in July. In turn, slight fluctuations of the index value (not more than 0.3 ) are characteristic for the cold half-year (October - March), particularly for the period from November to February - Fig. 2. According to Błażejczyk (2003), it is due to much greater variety of air masses and directions of air advection in the warm period in comparison with the cold period. It should be noted, however, that with the exception of June and July daily amplitudes of $\mathrm{HL}$ index were higher on the outskirts of the city than in the city centre, and the greatest variations $(\mathrm{HL}>0.09)$ were recorded in the February. As is presented in Fig. 2, the highest amplitude of the daily value of HL occurred most often in July and the 
maximum amplitude of daily $\mathrm{HL}$ was marked by July 11, 2010 year. In the city center daily amplitude $H L$ reached then the value of 3.39, and in the area of Łączna Street was 2.66. Daily course of $\mathrm{HL}$ indicates that the heat load recorded in the city on that day ranged from thermoneutral conditions for the human organism to burdening conditions connected with very strong cold stress, yet the intensity of the load was higher in the city centre than on the outskirts.

Table 2. Monthly and average value of heat loads index $(\mathrm{HL})$

Tabela 2. Średnie miesięczne i roczne wartości wskaźnika obciążenia cieplnego HL

\begin{tabular}{|c|c|c|c|c|c|c|c|c|c|c|c|c|c|c|}
\hline & \multicolumn{2}{|c|}{2005} & \multicolumn{2}{|c|}{2006} & \multicolumn{2}{|c|}{2007} & \multicolumn{2}{|c|}{2008} & \multicolumn{2}{|c|}{2009} & \multicolumn{2}{|c|}{2010} & \multicolumn{2}{|c|}{$2005-2010$} \\
\hline & $P$ & Ł & $P$ & 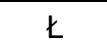 & $P$ & 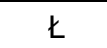 & $P$ & 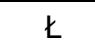 & $P$ & 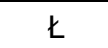 & $P$ & 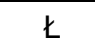 & $P$ & 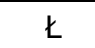 \\
\hline 1 & 0.883 & 0.806 & 0.857 & 0.802 & 0.875 & 0.798 & $b d$ & $b d$ & 0.876 & 0.823 & 0.841 & 0.781 & 0.867 & 0.802 \\
\hline II & 0.893 & 0.824 & 0.898 & 0.845 & 0.881 & 0.825 & 0.899 & 0.849 & 0.887 & 0.837 & 0.888 & 0.842 & 0.891 & 0.837 \\
\hline III & 0.910 & 0.856 & 0.911 & 0.863 & 0.929 & 0.885 & 0.901 & 0.854 & 0.920 & 0.877 & 0.926 & 0.880 & 0.916 & 0.869 \\
\hline IV & 0.977 & 0.933 & 0.956 & 0.920 & 1.007 & 0.953 & 0.988 & 0.964 & 1.027 & 1.004 & 0.966 & 0.927 & 0.987 & 0.949 \\
\hline V & 1.067 & 1.020 & 1.061 & 1.024 & 1.089 & 1.035 & 1.103 & 1.082 & 1.023 & 0.992 & 0.992 & 0.950 & 1.056 & 1.017 \\
\hline VI & 1.112 & 1.048 & 1.203 & 1.134 & 1.147 & 1.077 & 1.226 & 1.215 & 1.048 & 1.007 & 1.143 & 1.061 & 1.153 & 1.096 \\
\hline VII & 1.208 & 1.152 & 1.508 & 1.414 & 1.132 & 1.073 & 1.241 & 1.202 & 1.074 & 1.043 & 1.406 & 1.322 & 1.286 & 1.222 \\
\hline VIII & 1.095 & 1.045 & 1.076 & 1.028 & 1.088 & 1.038 & 1.114 & 1.102 & 1.192 & 1.191 & 1.105 & 1.057 & 1.112 & 1.077 \\
\hline IX & 1.082 & 1.039 & 1.071 & 1.023 & 0.980 & 0.942 & 1.011 & 0.975 & 1.037 & 1.020 & 0.992 & 0.945 & 1.029 & 0.990 \\
\hline$x$ & 0.956 & 0.907 & 0.960 & 0.922 & 0.948 & 0.905 & 0.947 & 0.903 & 0.937 & 0.890 & 0.922 & 0.878 & 0.945 & 0.901 \\
\hline$X I$ & 0.914 & 0.858 & 0.923 & 0.864 & 0.863 & 0.843 & 0.903 & 0.847 & 0.915 & 0.865 & 0.910 & 0.861 & 0.905 & 0.856 \\
\hline XII & 0.878 & 0.810 & 0.898 & 0.832 & 0.889 & 0.808 & 0.883 & 0.830 & 0.891 & 0.837 & 0.854 & 0.779 & 0.881 & 0.813 \\
\hline$I-X I \mid$ & 0.998 & 0.941 & 1.027 & 0.973 & 0.986 & 0.932 & 1.020 & 0.984 & 0.986 & 0.949 & 0.995 & 0.940 & 1.002 & 0.953 \\
\hline
\end{tabular}
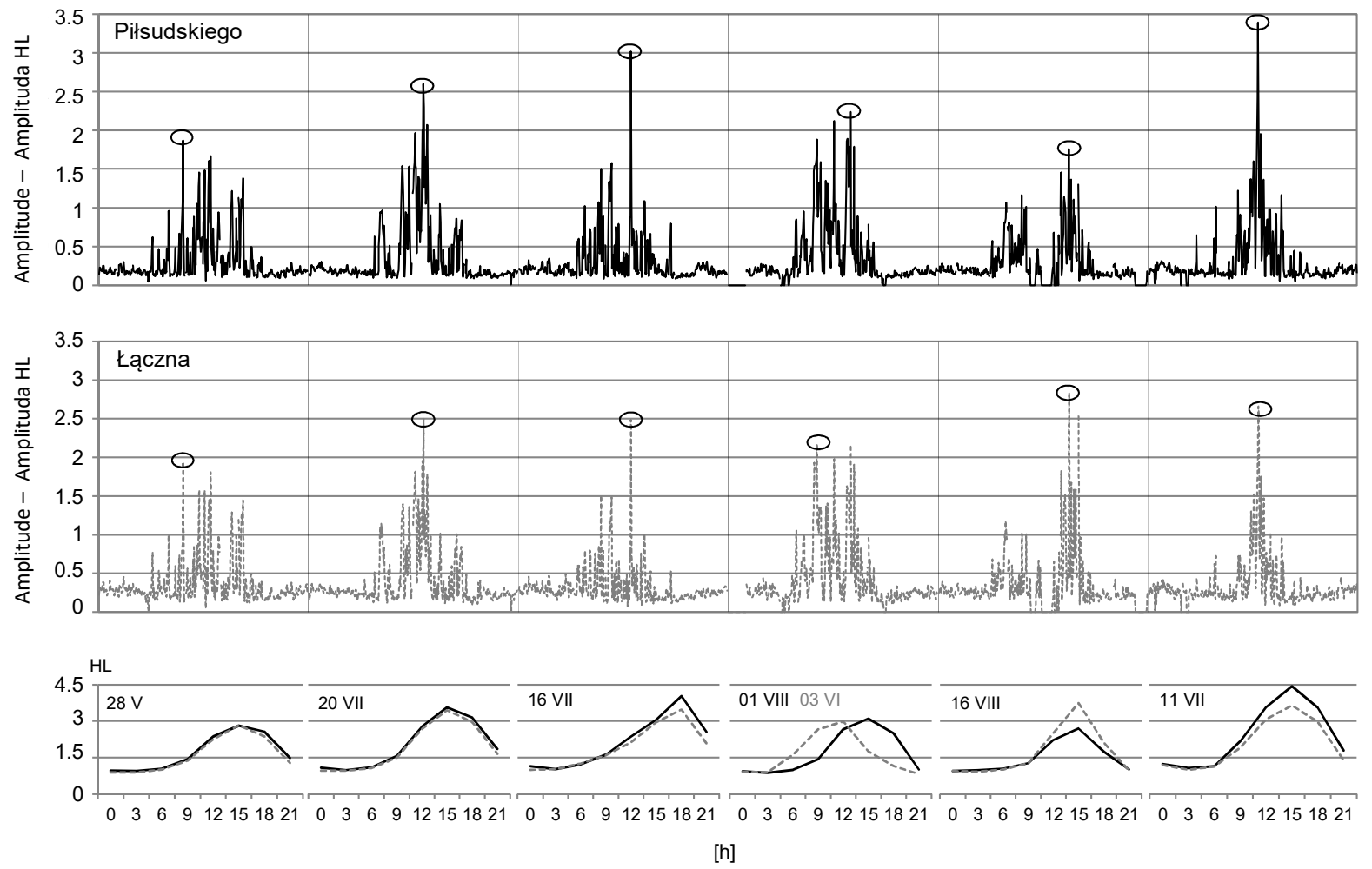

Fig. 2. The course of daily amplitude of thermal loads index $(\mathrm{HL})$ in following years in Szczecin Ryc. 2. Przebieg dobowych wartości amplitudy wskaźnika obciążeń cieplnych HL w kolejnych latach w Szczecinie 
Having determined HL index on the basis of its values, the frequency of heat load was assessed according to HL ranges by Kozłowska-Szczęsna et al. (1997) - Table 1, the conditions were considered as: saving, toughening and burdening.

The most desirable conditions, termed "saving", constitute a very slight heat load and are reflected by $\mathrm{HL}$ values ranging from 0.931 to 1.185 . The analysis demonstrated that such conditions occur in Szczecin most frequently, $52 \%$ of days in a year in the area of Piłsudskiego and $44 \%$ in the area of Łączna - Fig. 3. With respect to months, saving conditions are recorded in all months in a year, with the frequency of $25 \%(P, 七)$ in December to as much as $61 \%$ in August on the outskirts of the city, and to $77 \%$ in September in the city centre - Fig. 4 . What is particularly interesting is the frequency of heat load in a 24-hour period. As is presented in Fig. 5, weather conditions corresponding to thermal comfort (saving conditions) were recorded in both areas of the city each day $(100 \%)$ or almost each day (>98\%) from 9 a.m. to 12 in the cold half-year (September - March), at 6 a.m. in April, May, August and September, and at 3 p.m. in February, March and October. Such most desirable conditions were not found at the time of 6 p.m. -6 a.m. during the calendar winter (December - February).

Favourable or unfavourable reaction of an organism to atmospheric stimuli mostly depends on their intensity, yet the time of exposure as well as the adaptive abilities of the human organism, which to a large extend depend on age, sex, fitness and health, are also important (Tyczka 1990; Günter 2000). When the stimuli are too weak, they may cause the loss of natural adaptive abilities of an organism and result in excessive susceptibility. However, stimuli which are too strong may lead to burdening or overloading of the thermoregulatory system of the organism. Moderate intensity of the atmospheric stimuli has a stimulating, toughening and healing effect on the human body (Kozłowska-Szczęsna et al. 1997).

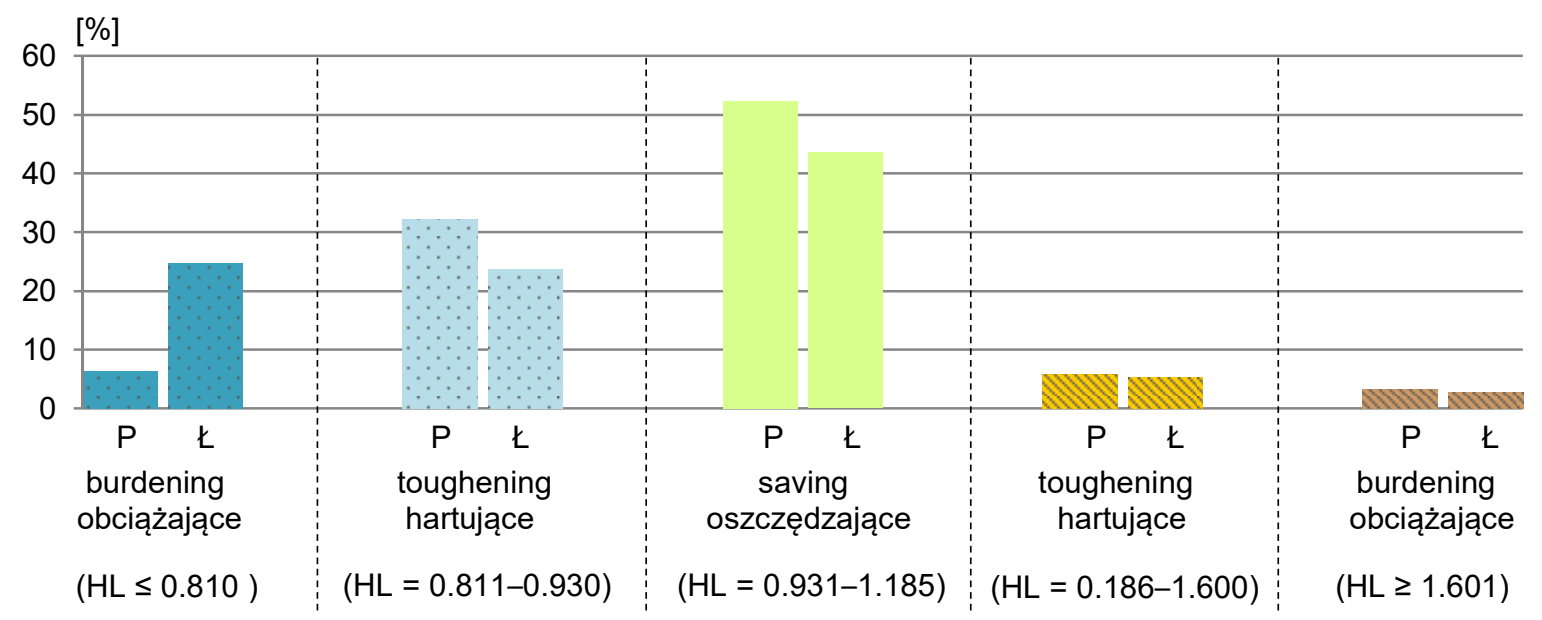

Fig. 3. The frequency of biothermal conditions in the center $(P)$ and outside $(Ł)$ Szczecin determined based on the heat loads index (HL). Years 2005-2010

Ryc. 3. Częstość warunków biotermicznych w centrum $(P)$ i na obrzeżach ( $($ ) Szczecina określona na podstawie wskaźnika obciążeń cieplnych HL. Lata 2005-2010 


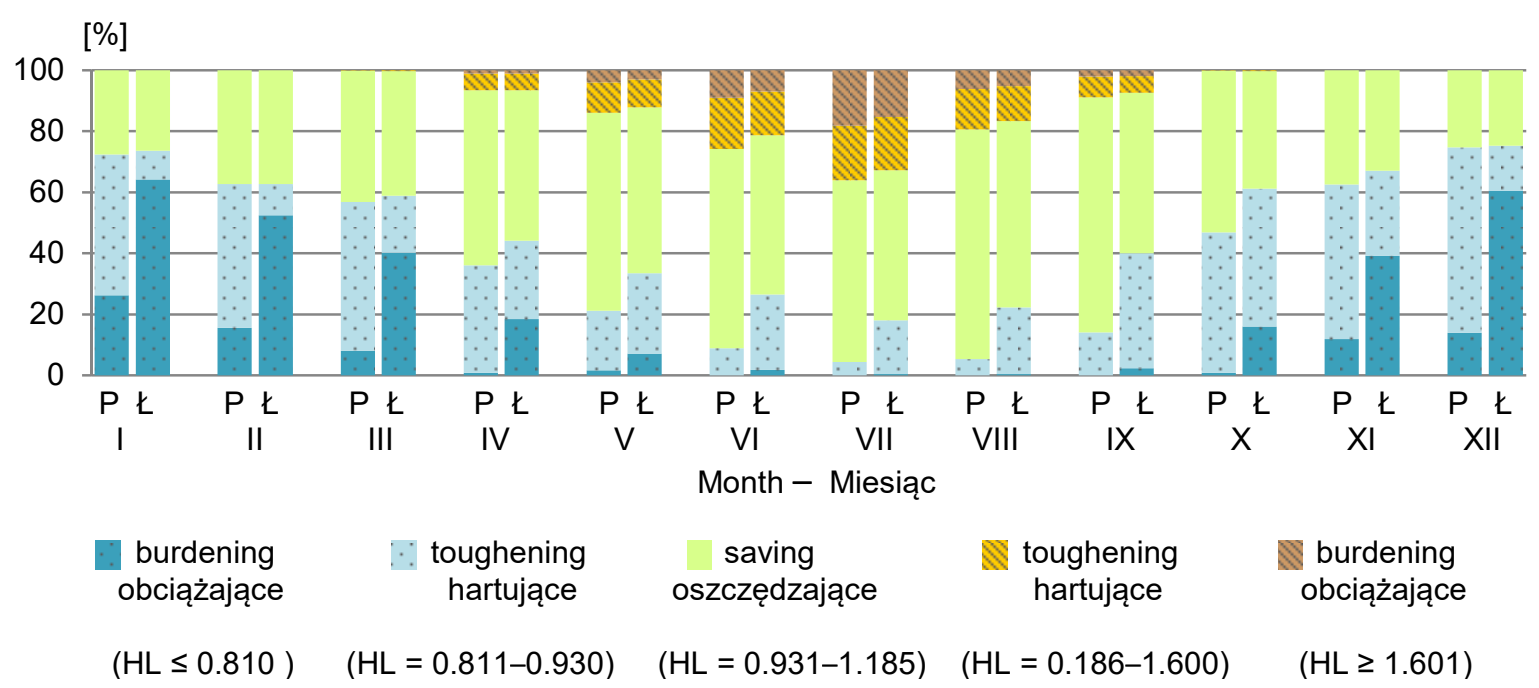

Fig. 4. The frequency of biothermal conditions in the center $(P)$ and outside $(\measuredangle)$ Szczecin determined based on the rate of heat loads $\mathrm{HL}$, in the following months

Ryc. 4. Częstość warunków biotermicznych w centrum $(P)$ i na obrzeżach $(Ł)$ Szczecina, określona na podstawie wskaźnika obciążeń cieplnych $(\mathrm{HL})$ w kolejnych miesiącach roku

Biothermal conditions termed "toughening" which correspond to $\mathrm{HL}$ values from 0.811 to 0.930 and from 1.186 to 1.600 , are characteristic for weather conditions with moderate and slight cold and warm stress. Such conditions have a stimulating effect on the human body and increase the thermoregulatory capacity of the human organism. These conditions are recorded in Szczecin, on average, with the frequency of $38 \%$ in the city centre and $29 \%$ on the northern outskirts (Fig. 3). Toughening conditions, corresponding to moderate and slight cold stress, are recorded each month in a year, however, more often in the city centre (P - 32\%, $Ł-22 \%)-$ Fig. 4. During the 24-hour period, such conditions were always recorded from 9 p.m. to 3 a.m. each month. In turn, toughening conditions corresponding to warm stress were found in the period from April to September with almost the same frequency in the city centre and on the outskirts, mainly from $12-6$ p.m. - Fig. 5 .

Biothermal conditions are termed "burdening" when $\mathrm{HL}$ values are $\leq 0.810$ and $\geq 1.601$. Within this range of $\mathrm{HI}$ values, the present weather conditions cause thermoregulatory distress which results from protection of the organism from excessive loss of body heat (cold stress) as well as elimination of excess heat (hot stress). The analysis demonstrates that the weather situations resulting in overloading of the human organism constitute approximately $10 \%$ of days in a year in the city centre and $27 \%$ on the outskirts - Fig. 3. Similarly to toughening conditions, burdening conditions resulted mainly from cold stress.

The greatest spatial and temporal variability of biothermal conditions concerns very strong and strong cold stress. As is presented in Fig. 3, cold stress was most frequently $(24.6 \%)$ recorded at Łączna Street as compared with Piłsudskiego Street where it was recorded almost four times less frequently. Additionally to the fact that cold stress was recorded more frequently on the outskirts of the city, it also lasted longer.

In comparison with the city centre, where such load is generally not recorded in the warm half-year (with the exception of a few days in April and May), the residents of the northern 
districts of Szczecin are at risk of cold stress almost all year. In the summer months, such weather situations occurred sporadically in the evening and at night (9 p.m. -3 a.m.) - Fig. 5 . In the cold half-year, and particularly in the period from November to March, the frequency of very strong and strong cold stress amounted to $15 \%$ in the city centre and $51 \%$ in the area of Łączna Street. These results are characteristic for the seaside area, as has been shown by Błażejczyk (2003).
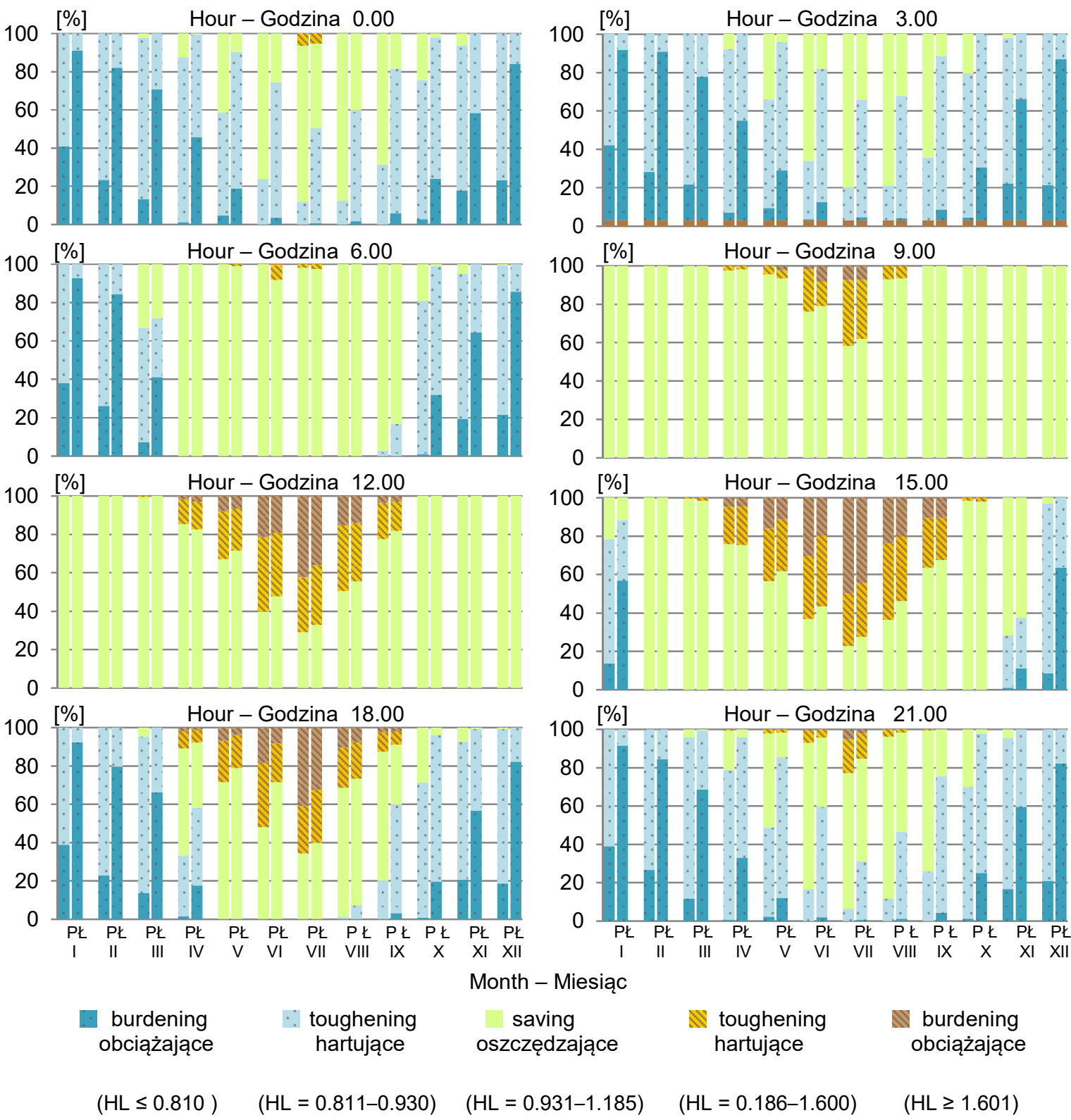

Fig. 5. The frequency of biothermal conditions in the center $(P)$ and outside ( $七$ ) Szczecin determined based on the rate of heat loads $\mathrm{HL}$, in the following months according hours

Ryc. 5. Częstość warunków biotermicznych w centrum $(P)$ i na obrzeżach $(Ł)$ Szczecina określona na podstawie wskaźnika obciążeń cieplnych $(\mathrm{HL})$ w kolejnych miesiącach roku, według godzin

Warm stress occurs with approximately $20 \%$ greater frequency in the city centre. Fortunately, very strong heat stress is rarely recorded in Szczecin, from April to September with the frequency of $3.3 \%(P)$ and $2.7 \%(Ł)$, which is in line with the findings by Błażejczyk 
(2003). By far the greatest frequency of such load was recorded in July ( $P-18.2 \%, \nvdash-15.2 \%)$, from 9 a.m. to 9 p.m. Particularly high values of $\mathrm{HL}$ index were determined in July 2006. With the exception of only three days, strong and very strong warm stress ( $H L \geq 1.601)$ were recorded in the city centre. This situation was also recorded on the outskirts, yet with slightly lower intensity - Fig. 6 . The occurrence of extreme biothermal conditions, particularly lasting several days, has a negative effect on human health. As was demonstrated by NidzgorskaLencewicz and Mąkosza (2013), in July 2006 the number of calls for an ambulance increased by $20.5 \%$ as compared with the average number of calls in July.
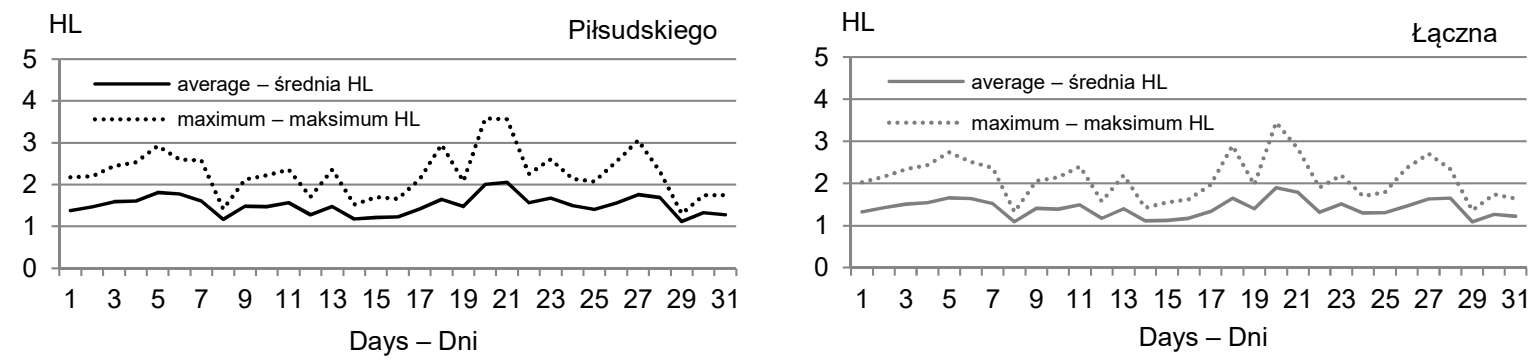

Fig. 6. The course of average and maximum daily value of the heat load index $(\mathrm{HL})$ in July of 2006 year in Szczecin

Ryc. 6. Przebieg średnich i maksymalnych dobowych wartości wskaźnika obciążenia cieplnego HL w lipcu 2006 roku w Szczecinie

\section{CONCLUSION}

The analysis of the value of heat load index HL in Szczecin in the period 2005-2010 demonstrates a pronounced spatial and temporal variability of biothermal conditions. It was found that $\mathrm{HL}$ values were higher in the densely built-up area of the city centre than on the northern outskirts of Szczecin. This thermal situation in the city centre is due to urban heat island which is considered the most characteristic feature of the urban area.

Biothermal conditions termed as saving are the most desirable conditions for the human organism. Such conditions constituted approximately $52 \%$ of days in a year in the city centre, and $44 \%$ on the outskirts. With respect to individual months, the share of days with such conditions ranges from $25 \%$ in December in both areas of the city, to even more than $75 \%$ in August and September in the city centre. It is noteworthy that regardless of the month, saving conditions were recorded most frequently at 9 a.m., and in the cold half-year the frequency was $100 \%$.

Toughening conditions connected with moderate and slight cold stress occur each month in a year from 9 p.m. to 3 a.m., and the frequency is higher in the city centre ( $P-32 \%, 七-22 \%)$. In turn, toughening conditions connected with warm stress occur by far less frequently $(P-5.9 \%$, $七-5.3 \%)$ in the warm half-year and show no spatial variability.

The conditions of very strong and strong cold as well as warm stress amounted to $10 \%$ of days in a year in the city centre and $27 \%$ on the outskirts. It is noteworthy that out of all the classes determined with the use of $\mathrm{HL}$ values, the greatest spatial as well as temporal 
variability was recorded for very strong and strong cold stress. Unfavourable cold stress was recorded four times more frequently on the outskirts $(P-24.6 \%,\llcorner-6.3 \%)$ than in the city centre. In turn, very strong and strong warm stress was recorded extremely rarely $(P-3.3 \%$, $七-2.7 \%)$, mostly in July.

\section{REFERENCES}

Błażejczyk K. 2003. Biotermiczne cechy klimatu Polski [Biothermal features of the climate of Poland]. Prz. Geogr. PAN 75(4), 525-543. [in Polish]

Błażejczyk K. 2004. Bioklimatyczne uwarunkowania rekreacji i turystyki [Bioclimatic principles of recreation and tourism in Poland]. Pr. Geogr. 192. [in Polish]

Błażejczyk K., Kuchcik M., Milewski P., Dudek W., Kręcisz B., Błażejczyk A., Szmyd J., Degórska B., Pałczyński C.M. 2014. Miejska wyspa ciepła w Warszawie: uwarunkowania klimatyczne i urbanistyczne. Warszawa, Wydaw. Akad. SEDNO Spółka z o.o. [in Polish]

Bogucki J. 1999. Biometeorologia turystyki i rekreacji. Poznań, AWF. [in Polish]

Czarnecka M., Mąkosza A., Nidzgorska-Lencewicz J. 2011. Variability of meteorological elements shaping biometeorological conditions in Szczecin. Pol. Theor. Appl. Climatol. 104(1), 101-110.

Dobek M., Krzyżewska A. 2016. Wybrane zagadnienia z bioklimatu Lublina [Selected aspects of Lublin bioclimate]. Ann. UMCS, Sec. B 70(2), 117-129. [in Polish]

Günter D.R. 2000. Pogoda i Klimat. Warszawa, Wydaw. Świat Książki. [in Polish]

Kozłowska-Szczęsna T., Błażejczyk K., Krawczyk B. 1997. Bioklimatologia człowieka. Metody i ich zastosowanie w badaniach bioklimatu Polski. Warszawa, IGiPZ PAN. [in Polish]

Kozłowska-Szczęsna T., Błażejczyk K., Krawczyk B., Limanówka D. 2002. Bioklimat uzdrowisk polskich i możliwości jego wykorzystania w lecznictwie [The bioclimate of Polish health resorts and the opportunities for its use in treatment]. Monogr. IGiPZ PAN Warsz. 3. [in Polish]

Kozłowska-Szczęsna T., Krawczyk B., Kuchcik M. 2004. Wpływ środowiska atmosferycznego na zdrowie i samopoczucie człowieka [The influence of atmospheric environment on the human health and well being]. Monogr. IGiPZ PAN Warsz. 4. [in Polish]

Krawczyk B. 2001. Ryzyko wystąpienia stresu ciepła w wybranych uzdrowiskach Polski [The heat stress hazard in the selected health resort]. Balneol. Pol. 43(1-2), 88-93. [in Polish]

Krawczyk B. 2003. Stres ciepła - cecha bioklimatu Polski. Postępy w badaniach klimatycznych i bioklimatycznych [Heat stress - a feature of Poland's bioclimate. Progress in climatic and bioclimatic research]. Pr. Geogr. IGiPZ PAN 188, 283-294. [in Polish]

Mąkosza A. 2013. Bioclimatic conditions of the Lubuskie Voivodeship. Geogr. Pol. 86(1), 37-46.

Nidzgorska-Lencewicz J. 2015. Variability of human-biometeorological conditions in Gdańsk. Pol. J. Environ. Stud. 24(1), 215-226.

Nidzgorska-Lencewicz J., Mąkosza A. 2013. Assessment of bioclimatic conditions within the area of Szczecin agglomeration. Meteorol. Zeitschrift 22(5), 615-626.

Tyczka S. 1990. Ekologiczne uwarunkowania zdrowia i choroby [Ecological conditions of Health and Disease]. Probl. Uzdrowisk. 1-2, 117-150. [in Polish]

Abstract. On the basis of hourly values of air temperature, relative humidity of air, wind speed and cloudiness, the dimensionless index of heal load (HL) was determined for two stations in Szczecin representing the very city centre (Piłsudskiego Street) and its northern outskirts (Łaczna Street). The analysis of HL values for the period 2005-2010 demonstrates a pronounced spatial as well as temporal variability of biothermal conditions in Szczecin. It was found that regardless of the analysed time period, higher values of $\mathrm{HL}$ were recorded in the city centre than on the outskirts. The frequency of saving conditions (HL 0.931-1.185) in a year was, on average, 
$52 \%$ in the city centre and $44 \%$ on the outskirts. The toughening conditions ( $\mathrm{HL} 0.811-0.930$, $1.186-1.600$ ) were recorded with the frequency of total $38 \%$ (Piłsudskiego Street) and $29 \%$ (Łączna Street). The least favourable biothermal conditions $(H L \leq 0.750 \geq 1.750)$ with the greatest load on the human organism occurred only on $10 \%$ of days in a year in the city centre and $27 \%$ of days on the outskirts of Szczecin. 
